\title{
Effects of Interest Rate and Exchange Rate on the Stock Market Performance of Pakistan: A Cointegration Approach
}

\author{
Waqar Khalid* \\ School of Economics, Quaid-I-Azam University, Islamabad, Pakistan \\ *Corresponding author: waqarkhalidicp@yahoo.com
}

\begin{abstract}
This research paper is an endeavor to empirically investigate the economic effects of interest rates and exchange rates on stock market capitalization by considering annual data for Pakistan covering the 1990-2017 periods. The main intention of this research is to analyze the short-run together with the long-run interconnections between the aggregate market capitalization and macroeconomic variables by employing the econometric tools of Johansen approach, Error Correction Model (ECM) and then inspection of Variance Decomposition. And finally, causal linkages have been explored by the application of Granger-Causality test. By applying the Johansen Jeselius approach, it is detected that the whole series of data are co-integrated showing the long-term relationships among the examined variables. The long-term coefficient shows that a $1 \%$ increase in interest rate and in exchange rate contributes $0.23 \%$ decrease and $3.17 \%$ increase in market capitalization, respectively. The estimated ECM lagged value illustrates that in the short period, $22.07 \%$ volatility of market capitalization are corrected per annum to reach at the steady-state. And the analysis of Granger-causality tool reports the existence of a unidirectional causality from foreign exchange rate to interest rate. The further reduction of bank rate in the economy has been recommended in this study to facilitate the financial sector development as well as to stimulate the investment level both nationally and internationally.
\end{abstract}

Keywords: interest rate, exchange rate, market capitalization, short-run, long-run, johansen approach, error correction, granger causality, stock market, Pakistan

JEL Classification Codes: E43, F31

Cite This Article: Waqar Khalid, "Effects of Interest Rate and Exchange Rate on the Stock Market Performance of Pakistan: A Cointegration Approach.” Journal of Finance and Economics, vol. 5, no. 5 (2017): 219-232. doi: 10.12691/jfe-5-5-4.

\section{Introduction}

A well-functioning and a well-developed financial system play a key role in the economic progress of a nation. The efficient and effective utilization of capital resources in the financial market is the imperative job of a well-organized financial system. Through this mechanism, savers provide their surplus income to the financial system with the expectations to achieve the highest rate of return in future. Conversely, borrowers demand funds from the same system with the understanding that they will be mandatory to repay the amount with the interest in the future. Through the mobilization of such funds, it generates savings, which in turn, available in various fields of the economy including agriculture and industry.

The stock market performance is one of the leading dynamics which affects the economic progress of a nation and may have practical implications for economic variables to accomplish the preferred outcomes. Such market performance is highly influenced by many variables, but especially due to interest rate as well as exchange rate [1]. The stock market development level, domestic currency value and the interest rate level give details of the dynamics in the development level of an economy [2]. As well, one of the changes such as the structural changes in the equity market has been noteworthy [3]. There are various research works which have examined the consequences of movements in economic factors on the equity market performance. Among a list of such factors, the most widely debated economic factors are the policy rates and currency rates which put forward a considerable influence on major indicators of the stock market performance [4]. Hence, the short plus long type connection of the stock market performance with interest rates plus exchange rates is an imperative area for economists and financial researchers and is widely debated being its due role to offer input to regulators in reforms of the equity market development.

The finance theory suggests that there is an association among these series, both in the short-run plus long-run. Such as, if the state bank increases the bank rate from its previous level, this policy step would clue investors to find the money market for their investments, if other variables do not change. Conversely, if the interest rate 
decreases by the central bank from its prior level, this change would be a signal for investors to mobilize their funds into the stock markets giving a better reward. But this move in investments is possible only if both the prescribed markets are perfectly close substitutes to each other in the long-run. A converse and significant link between bank rate \& stock performance has existed in the work done by Ahmad et al. [5]. Similarly, the interest rate shows a negative and significant relationship with the stock prices in the long term [4].

There is a wide range of elements which can affect the behavior of market volatility, but the most important among all the factors is the exchange rates which have attracted the attention of not only economists and policymakers, but the investment community as well for a long time [6]. The exchange rates develop the underlying stock market performance [7]. The disorder in equity markets can be prohibited from maintaining a proper check on the existing exchange rates. Then again, if stock prices influence the exchange rates of a country, in that case steps may be implemented to regularize the normal workings of stock markets. Depreciation of currency in a country increases those firms competitiveness that are involved in export trade because the value of such stocks will pursue a rising trend and the anticipation is that overseas investors are attracted to the domestic stock market. The exchange rate has a constructive influence on the stock return in the long term [4] and significant relation has been concluded for the same variables in the study conducted by [5]. Though, Aslam [8] put forward that the correlation between stock market performance and the domestic currency is negative. Whereas, the empirical study taken by Ihsan et al. [9] revealed no evidence for association between $\mathrm{Fx}$ rate and market indices for Pakistan.

The Pakistan's economy is one of the essential regional economies. Though, uncertainty in the shape of wars, earthquakes, floods, shocks, etc. and frequent political instability has badly affected the economic performance of the economy in question over the last two to three decades. But no one can deny the fact that the Pakistan economy has tremendous capacity to achieve high levels of economic efficiency by way of equivalent development in major sectors. The verdicts may too be noticed on the currency, which has largely depreciated against the foreign currencies by a large margin in recent times with immediate effects on macroeconomic indicators used to assess the economic position and the market index is certainly one of them.

The present democratic government, which was elected in 2013 with the majority public mandate has dedicated serious efforts to reform and in this respect, certain measures have been in action to stop the continuous declining rate of PKR/US\$ and encourage steps helpful in equity market development. Despite the pluses and minuses of the current government interest, to a degree the currency value has appreciated against the USD for a shorter time, but the major confronts is whether a targeted point of currency parity will be sustained in the presence of the immense challenges facing the economy of Pakistan today. And more essentially, the interlinked economic effects may be checked on the stock market indicator, which is an eminent indicator and the investors use it as a yardstick to invest their past and current savings in the stock market. This research study is also an endeavor to empirically consider the effects of policy rates and foreign exchange rates on the stock market performance as measured by the aggregate market capitalization. The empirical relations of these variables may present an idea to investors living anywhere and provides a knowledge base for financial experts and concerned government bodies to make profitable decisions which develop the significance of the current empirical work.

\subsection{Pakistan Stock Exchange (PSX)}

In this research work, we are going to test the short plus long term connection of the interest rate and exchange rate on the equity market performance by taking yearly dataset covering the 1990-2017 periods. On September 18, 1947, the Karachi Stock Exchange (KSE) was introduced which was initially considered the biggest stock exchange in the region on the basis of market capitalization. At the start, a total number of five companies were registered and the KSE-50 index was set up to capture its performance, which was based on 50 financial companies, and with times more companies were appearing in the list of the KSE due to the enhancement of trading activities in volume. Hence, to better capture the stock market performance, the KSE-50 index was changed into the PSX index in November 1991 with a reference value of 1,000. The KSE-100 indicator consists of top hundred listed firms selected from different sectors in terms of highest market capitalization. There are many indicators which are used for measuring the stock market performance of Pakistan, but the most accepted indicators is the stock market capitalization which is widely used by many studies like Kanasro et al. [10], Sichoongwe [11], etc. The KSE-100 index captures about $90 \%$ of the market capitalization of listed companies [9].

With effect from 11 January, 2016, all the three equity markets were integrated into one equity market, commonly known as the Pakistan Stock Exchange which provides a sole platform to foreign investors mostly. Latest statistics show that the PSX-100 index was a top ranked market in South Asia and stood in $5^{\text {th }}$ position as a finest performing stock market across the boundaries in 2016 by Bloomberg. Starting from July 1, 2016 up to May 8,2017 , the covered time span witnessed an upward trend of the market performance. The PSX market showed marvelous performance over the stated period largely because of reforms undertaken by the Securities and Exchange Commission of Pakistan (SECP), better macroeconomic indicators, improved security conditions, and the rest. On June 30, 2016, the amount of the stock market capitalization was 7,588.47 billion rupees and on May 08, 2017, such amount increased to 10,044.07 billion rupees, showing a growth of $32.4 \%$ in total. Too, the average daily volume of 379.1 million shares was witnessed during July 2016 to March 2017 which shows a three times increase as compare to previous periods (Pakistan Economic Survey, 2016/17). 


\subsection{Problem Statement}

The stock market volatility and its impact on the economy is the core interest area of research for economists, financial analysts and business community due to its leading role in the economic development. The finance theory suggests that variation of the equity market is extensively interlinked with various factors. Among the class of those variables, the fluctuations in both interest rates plus exchange rate are reviewed to be the major variables which can apply a momentous effect on the equity market performance. A change in policy rate is an essential economic and financial feature influencing the value of stock market return [12].

Irrespective of the theoretical association between stock market performance and these factors, the empirical evidence suggests that there exists a clear dichotomy about the connections between stock market volatility and financial factors. Minuscule idea about the relationship of interest plus the exchange rate with market volatility is the major issue of investors, which can adversely affect their future profitability. Since the association between stock market return and these factors is not obvious, it is obligatory for researchers to explore the existing behaviour of the variables. But surprisingly, a dearth of empirical studies exists in Pakistan to explore the interactions between equity market volatility and these elements. Though some studies are available on the same concern, but mostly they have investigated the interactions between exchange rate and the KSE-100 index. And there is no study found who tried to examine the relationships between the said determinants and market capitalization. Therefore, this research is an endeavour to fill the empirical research gap and to look into the short-run as well as long-run linkage of stock market volatility with these variables. To my knowledge, this study is the opening of its nature at the countrywide level of Pakistan since the Asian crisis of 1997/98.

\subsection{Research Questions}

This study has the following three research questions.

(1) Is bank rate and foreign exchange rate having a significant correspondence with the equity market performance of Pakistan?

(2) Is there any short and long-run interrelation prevail between stock market performance and interest rate-exchange rate in Pakistan?

(3) Is there any directional causal interconnection exist between market capitalization and interest rate and exchange in Pakistan?

\subsection{Research Objectives}

This study has the following four objectives.

(1) To empirically probe the effects of interest rate and exchange rate changes on the equity market performance of Pakistan in both time setups.

(2) To find out whether the stock market capitalization is significantly influenced by interest rate plus exchange rate in a time series arrangement.

(3) To factually explore the short-run and long-run dynamic aspects of market capitalization plus other variables influences and to detect the difference in both periods on market performance of the PSX.

(4) To explore whether there exists a causal relationship between market capitalization and macroeconomic variables or not.

After the introduction chapter, the remaining paper will proceed as given. Section 2 reviews the existing literature on the study. Section 3 presents a detailed illustration of the variables and its sources. Section 4 deals with the methodology and estimation procedure, including the Johansen Jeselius estimation strategy. Empirical findings of the study are discussed in Section 5. Last of all, Section 6 concludes this study with some policy implications.

\section{Literature Review}

An extensive number of research articles are present worldwide examining the relationship between equity market performance and economic determinants for the last so many years. In recent times, a lot of empirical attempts focus on the dynamic linkages between the equity market performance and interest rate-exchange rate.

The earlier studies such as Modigliani [13] and Mishkin [14] concluded that a smaller interest rate rise in stock prices which sequentially lead to improved investment activity. In general, a small interest rate directs privileged capital flows to the equity market in anticipation for a higher profit where a high rate of interest endorses more saving amounts in the banking sector and accordingly lessens the capital flow to the open equity markets. The empirical article conducted by Fama and Schwert [15] concludes a converse association between stock returns and rates of T-bills. Mukit [4] probed the upshots of interest rate on the equity market return by treating annual values from 1991 to 2012. The Johansen procedure demonstrates that the policy rate shows an inverse and significant relationship with the stock prices in the longperiod and also there exist at least one cointegrating equation between the series. The Granger causality analysis notes that there found a unidirectional causal association from bank rates to stock prices. A recent dynamic research analyzed by Mukit [16] reviewed the economic influences of bank rates on equity market volatility by employing monthly data over the periods of 1991-2012 for the Bangladesh's economy. A cointegrating test indicates a significant and stable long-run connection between the selected variables. It has also been concluded that a $1 \%$ rise in interest rate causes a 13.20 percent reduction in market index in the long-run. The ECT estimated value shows that $0.12 \%$ variation of stock market returns is corrected in the short term. The result of the impulse response function also confirms the converse relationship between the mentioned variables. The result of the Granger-causality affirms the presence of a unidirectional causal correspondence running from interest rates to a stock market index.

A huge quantity of researches investigating the dynamic bond between exchange rates-stock market performance and all these empirical studies provide mixed results about the association between the said variables. Kasman [17] analyzed the linkage betwixt exchange rate-stock prices in the stock market of Turkey by using a high frequency data. 
The numerical results of Johansen approach provide empirical evidence that a long period connection exists between stock prices-currency rates. What's more, the findings of the Granger causality analysis signify a unidirectional causal association between the two series, hence; the causality relation exists from the exchange rate to industry sector index. For the stock market of India, Nath and Samanta [18] have inspected the dynamic and causal relationship of the exchange rate with stock market return by encountering daily data covering the periods of March 1993 to December 2003. The outcomes prove that the causal linkage between the two markets is commonly absent, however, in recent periods, a strong causal relationship has been found from an equity market return to exchange return. Similarly, Kutty [6] studied the empirical connection of the exchange rate-stock prices in Mexican's stock market while using the weekly data for the year of Jan-1989 to Dec-2006. The outcomes of cointegration test presents that there is no long-time correlation exists between the examined data. While the Granger-causality inspection recommends for the shortterm link between the explored data.

A same kind of analysis has been carried out by Ihsan et al. [9] in Pakistan and checked for the interrelation between exchange rate-market indexes. Utilizing the daily data covering the phase of September 2012 to May 2014, the outcomes of the Johansen technique report that there is an absence of long-run involvement exists between currency rates with KSE-100 index. Whereas, the Granger causality test concludes that the currency rate doesn't cause the PSX index. Employing the GARCH model, Mlambo et al. [19] assessed the economic impacts of exchange rate changes on the stock exchange of Johannesburg by using monthly South African data set over the 2000-2010 periods. After estimating the model, they found a weak linkage for exchange rate changes and the JSE marketplace. Further, the impact of prime overdraft rate plus total mining production on the market capitalization was found negative. But surprisingly, the impact of interest rate of the U.S. on the market capitalization was found positive. Using the ARCH family and Johansen cointegration models, Bhat and Shah [20] explored the correlation between stock volatility and changes in currency rate for Pakistan using a weekly time series for the 1997-2013 periods. The empirics of Johansen co-integration model conclude that both the examined variables are co-integrated with each other in the long-run. And the Granger causality verdicts confirm the bi-directional causal association between the two series under examination.

Solnik [21] modeled the economic effects of various factors, including policy rate, currency rate and inflation on stock prices for nine western economies, including France, UK, Switzerland, Canada, U.S., Belgium, Netherlands, Germany and Japan by using monthly dataset. After empirical investigation, he concludes devaluation to have a constructive but an inconsiderable effect on the U.S. equity marketplace as contrasted to variation in inflationary prospect and policy rates. In the same way, Hasan and Javed [22] discovered the long-run relationship of the PSX with various determinants such as currency rate, T-bill rate, money supply plus the inflation rate. The analysis of cointegration, Granger causality and impulse response shows that there exists an inverse relationship of the equity market with interest rates \& exchange rates. Besides, Ahmad et al. [5] studied the influence of interest rate as well as foreign exchange rate on the KSE-100 index of Pakistan uses the data covering the 1998-2009 periods while applying the multiple regression models. The outcomes of the model concluded that there found a negative and significant linkage of the interest rate and exchange rate with the selected stock index.

Geetha et al. [23] have reinvestigated the interconnection between the equity market and macroeconomic indicators like expected plus unexpected inflation, interest rate, exchange rate and GDP for three selected countries, which are China, Malaysia and U.S. The results of the Johansen procedure confirmed about the long-term associations among determinants under examination for the whole countries. The findings of the ECM report the absence of the short period equilibrium association between market index and the rest of the variables for Malaysia and United States. Though, China's ECM verdicts reveal that there is a short-term link exists between equity market in China and anticipated inflation.

And finally, Mukit [4] extended the influences of the interest rates plus the exchange rates on equity market return by selecting monthly data for Bangladesh, covering the 1997-2010 periods. By estimating the cointegration technique, it was observed that a $1 \%$ rise in policy rate plus the currency rate contributes 1.71 percent and 1.04 percent decline in stock index, equally. The ECM value shows that $7.8 \%$ variation of stock returns is covered in the short term. And lastly, the result of the Granger causality affirms the subsistence of a unidirectional causal relationship running from the stock index to currency rate plus from policy rates to a stock index.

\section{Data Description}

The variables under consideration in this paper consist of annual data on the market capitalization, interest rate and exchange rate for Pakistan covering the periods starting from 1990 to 2017. The stock market capitalization (also called the market value or market cap) has been placed as a proxy for measuring the equity market performance of Pakistan. Market capitalization is the share price times the number of shares outstanding, and can be written as in the below formula:

$$
\begin{aligned}
& \text { Market Capitalization }(M C) \\
& =\text { Current Stock Price }(P) \\
& \times \text { Shares Outstanding }(N) .
\end{aligned}
$$

Data on the aggregate market capitalization are in current Pakistani rupees (Rs. billion) and has been taken from different Economic Surveys of Pakistan and its statistical supplements, published by the Ministry of Finance, Pakistan (1990-2017). The interest rate has been proxy by the discount rate/bank rate, commonly known as the SBP's Reverse Repo (Ceiling) rate ${ }^{1}$. The interest rate

\footnotetext{
${ }^{1}$ This rate is formally known as the SBP 3-day repo rate which was renamed since Aug 17, 2009. This is the rate at which domestic banks borrow from SBP on an overnight basis. Also, at this rate the banks deposit their end-of-day excess cash with SBP on an overnight basis. It remained as SBP Policy rate till May 24, 2015.
} 
change has been calculated by taking log-difference to bank rate, and can be written as:

$$
\text { Change in Interest rate }=\ln \left(\frac{I R_{t}}{I R_{t-1}}\right) .
$$

Numerical data on the interest rate has been taken from the State Bank of Pakistan until 2016 and the rest series have been updated from the Monetary Policy Statements and the latest Pakistan Economic Survey. And finally, the variable exchange rate is the price or purchasing power of the home currency in term of foreign currency. More to the point, the exchange rate is narrated in units of Pakistani rupee (PKR) in terms of the U.S. dollar (USD), and can be calculated as:

\section{Change in foreign exchange rate $(\triangle F E R)$}

$$
=\ln \left(\frac{F E R_{t}}{F E R_{t-1}}\right) \text {. }
$$

(a) $\ln \mathrm{EX}$

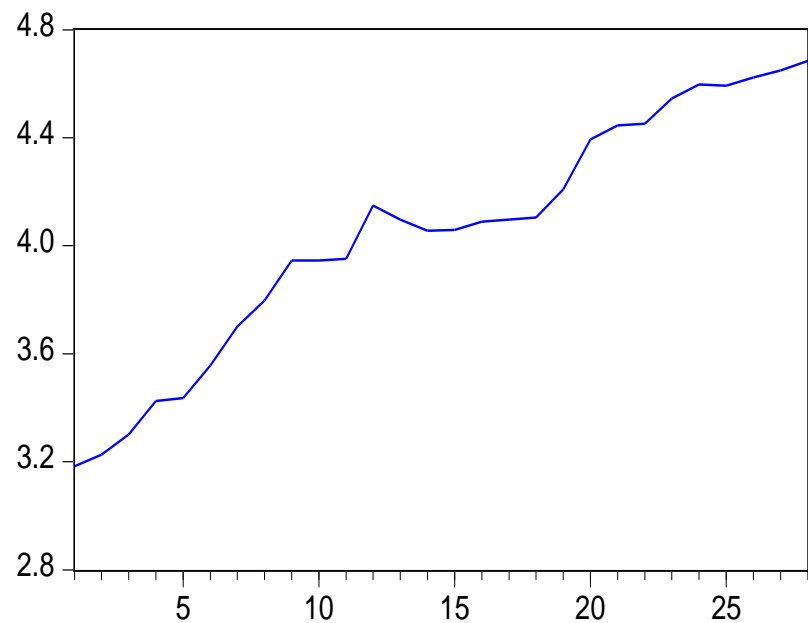

Years
Data on the average exchange rate has been extracted from the Statistics and Data Warehouse Department, State Bank of Pakistan up to 2012 and the remaining sample values have been taken from different departments of the State Bank of Pakistan (2017).

A few statistical transformations have been made in the collected dataset to avoid from meaningless regression as well as to present an effective set of policy measures. Such as, the variable that was basically available in the percentage form has been converted to the decimal notation. Likewise, all variables under examination are changed to the natural log to outfit the operation of variance. One of the advantages of the natural log transformation is that we get a smaller value of the coefficients after estimating them and hence, we can easily interpret the estimates for results.

Figure 1 describes the plot of all variables over the selected time span, depicting more or less upward trend for exchange rate and aggregate market capitalization, while; the overall downward trend has been found for interest rate. (b) $\ln I R$

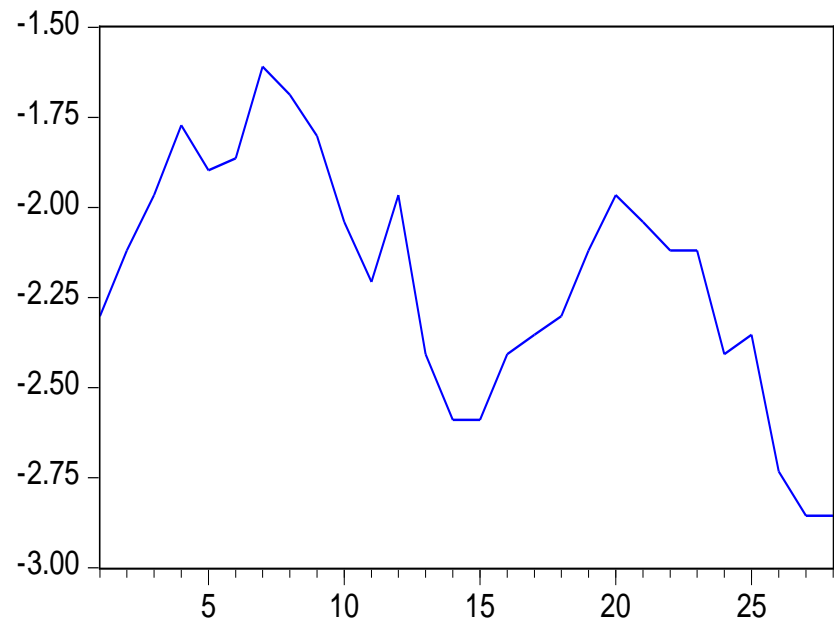

Years

(c) $\operatorname{lnMC}$

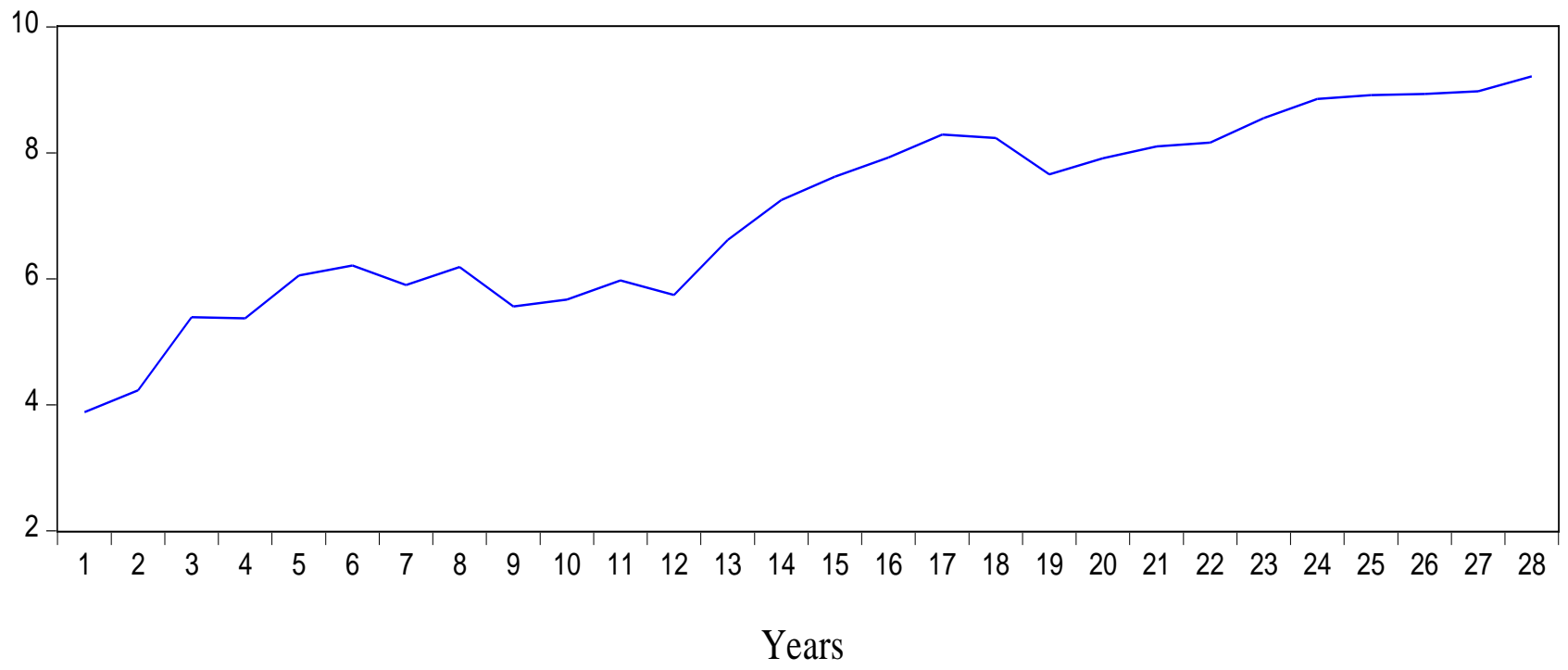

Figure 1. Plot of all variables over the selected sample size (1990-2017) (Source: Results extracted from the EViews 9) 
The above three figures offer a glance at the historical background of the Pakistan economy. From the rising exchange rate scatter plot (a), one can clearly perceive an idea that the Pakistan's currency has been quickly depreciated against the USD over the last two decades ${ }^{2}$. There are different reasons of currency depreciation in Pakistan, which includes economic, political and corruption. The responsible interconnected economic reasons include the fiscal deficit, price shocks, faulty financial system, speculative pressure, expansionary fiscal plus monetary policy, real exchange rate, capital flight, lower foreign direct investment, and so on. Despite the mentioned facts, the Pakistan rupee has remained stable at the rate Rs. $104 / \$$ in the open market roughly for the last two years due to the SBP's prudent management and effective monetary policy.

The plot (b) of interest rate illustrates the \% age change in the bank rate for each period from 1990 where the ups and downs can be clearly seen. It shows that initially this policy rate was set high at $13 \%$ in October FY91, where further increased at the rate has seen from the SBP's side and this rate reached to $14 \%$ in January FY92. Furthermore, the central bank also increased the bank rate from 9\% to 9.5\% (Economic Survey, 2005/06), and such increase in rate has remained high during the end of $\mathrm{FY}_{12}{ }^{3}$. The increase in policy rates was in accord with the foreign rising trend as well as such steps were also taken to shorten the advancing ability of the banks to the private segment. This policy designed to curtail domestic aggregate demand from the private sector that was one of the foremost driving forces for fuelling inflation. The plot of exchange rate shows that the policy rate is continuously falling from its peak over the last few years. To ensure the economic stability on the national level, the central bank kept the bank rate at 5.75\% in FY17 and continued the same during the successive periods. ${ }^{4}$ Likewise, the plot (c) of the aggregate market capitalization showing a continuous upward trend which in turn demonstrates boom in the stock market with the inclusion of new firms and companies investment as well as the policy measures taken by the SECP.

\section{Methodology and Estimation Procedure}

This study proposes the empirical framework in Mukit [4,16], Mbulawa [2], Ihsan et al. [9], Rabia and Khakan [24], Sichoongwe [11], and Kennedy and Nourizad [25] in estimating relationship of the aggregate market capitalization with interest rates and exchange rates. These studies estimated the structural model to investigate the interactions between equity market performance with interest rates as well as exchange rates in the log transformed form. The finance theory suggests that the equity market performance can be highly influenced with the movements in interest rate along with the exchange rate, hence; the proposed model to empirically explore the relations

${ }^{2}$ Pakistan's rupee against the USD depreciated by about $17 \%$ both in the open market and inter-bank during the fiscal year 2000-01 (Economic Survey, 2000-01).

${ }^{3}$ It was 12\% in July 27, 2012.

${ }^{4}$ It is the lowest policy rate by the SBP since early 1970s. between log-transformed series can be stated as in equation 1.

$$
\ln M C_{t}=\beta_{1}+\beta_{I R} \ln I R_{t}+\beta_{E X} \ln E X_{t}+\varepsilon_{t}
$$

Where,

$\ln M C_{t}=\log$ of the stock market capitalization at period $t$

$\ln I R_{t}=\log$ of the bank rate at period $t$

$\ln E X_{t}=\log$ of the exchange rate at period $t$

$\beta_{1}=$ intercept

$\beta_{i}=$ slope coefficients of the independent variables

$\varepsilon_{t}=$ error term

$t=$ number of years.

We have converted the basic linear illustration of the model into the log-linear form ${ }^{5}$ due to the reason that it gives more efficient results and avoid non-sense regression as compare to the original functional specification [26] and Ehrlich [27,28]. Also, such sort of conversion in variables provides elasticity estimates in the form of coefficients which a researcher can directly interpret for policy purposes.

The finance theory implies that if the interest rate falls, the investments with fixed income turn out to be less competitive due to their lower returns, so consequently, stocks turn out to be more attractive. In opposition, when interest rate increases, the investments with fixed income turn out to be more competitive due to their higher returns, and as a consequence, stocks become less striking. This logic, suggesting that there is an opposite association of the stock valuations with the bank rates. Therefore, we expect $\beta_{I R}<0$.

On the contrary, there exists a clear dichotomy in the finance theory on the correlation of equity returns with currency rates. Some of the studies recommend that there exists a direct correspondence between the stock prices plus the exchange rate, for instance, Aggarwal [29], Smith [30], Sabri [31], Ahmad et al. [5], etc. In contrast, other empirical works have concluded a converse link between equity prices and currency rates, and such studies include Soenen and Hanniger [32], Granger et al. [33], Yusuf and Rahman [34], etc. Hence, we expect $\beta_{E X}>0$ or $\beta_{E X}<0$.

With the intention of checking multicollinearity among the explanatory variables under examination, a correlation test has been recommended in the literature. Originally multicollinearity refers a situation in which two or more exogenous variables in a multiple regression analysis are extremely linearly correlated. Based on the rule of thumb, if intercorrelation between two independent variables is greater than 0.80 , then we have a significant multicollinearity in the data. The sign of the Pearson correlation coefficient (PCC) test decides about the nature of the relationship, whereas, its coefficients calculate the strength of the relationship between the pairwise correlations.

In order to escape from the meaningless estimates, the variables included in the model must be stationary since it is not possible to obtain reliable estimates and making forecasting with a nonstationary dataset. There are many tests in Econometrics for such purpose, but the widely used and the most famous amongst them over the last numerous years are the unit root tests [35]. For such a purpose, there are many tests in the literature, including

${ }^{5}$ It is the model type where both the explained and explanatory variables appear in logarithmic form. 
the Dickey-Fuller test, Phillips-Perron test, Ng-Perron test, Augmented Dickey-Fuller (ADF) test, etc. The most frequently demonstrated test amongst all for checking stationarity on a set of data is the ADF test because of its quality of relaxing the assumption of autocorrelation among residuals. The following shape of the ADF test has been chosen for analysis.

$$
\Delta Y_{t}=\beta_{1}+\beta_{2} t+\sigma Y_{t-1}+\alpha_{i} \sum \Delta Y_{t-i}+\varepsilon_{t} .
$$

In equation $2, \varepsilon_{t}$ is the stochastic error term and $\Delta Y_{t-1}=Y_{t-1}-Y_{t-2}$ and so forth are the no of lagged difference term which is determined empirically. Choosing the SIC measure, the optimal lag length is chosen mechanically by the EViews 9 version for testing the following hypotheses of the ADF test.

$\mathrm{H}_{0}$ : Variable is having a unit root

$\mathrm{H}_{1}$ : Variable is stationary.

The subsequently important step is to decide whether the given data have a non-meaningless co-integrating association with one another. Cointegration of two or more than two time series variables implies that there exists an equilibrium linkage between them. Hence, if the linear combination of two stochastic series becomes stationary, the variables are said to be cointegrated. And if the variables do cointegrate with each other, in that case we have a cointegrating property [36], and hence, the model in equation 1 is known as the long-run model. A large no of procedures for finding cointegration among variables have been suggested in the theory. And the selection of procedure relies on the order of stationarity of data. As all the variables are co-integrated at their first difference, therefore; the appropriate cointegration method is the Johansen and Juselius [37] methodology as suggested by many studies such as Mukit [4,16], Mbulawa [2], Ihsan et al. [9], etc.

The Johansen methodology is employed to test the combined movement of two time series variables over a given time span. This procedure tests the evidence of co-integrating equations in all the stochastic series of data. The rationalization for employing the cointegration technique is that while a number of certain developments can build permanent changes in a given series, there is a long-term association in data at the equilibrium state which binds jointly the given series as reflected all the way through their linear combination. Therefore, if such an important cointegrating property during the empirical analysis of time series variables is ignored, then it may cause in meaningless results which occurs if deliberately non-stationary series of variables (e.g. $\ln M C_{t}$ ) is regressed on explanatory variables of the model [9].

If the variables are cointegrated with each other, then the short-term association between the chosen series of data can be effectively estimated by investigating the Error Correction Model as we have a single equation model, which is given in equation 3 as follows ${ }^{6}$ :

$$
\begin{aligned}
& \Delta \operatorname{lnMC_{t}}=\delta_{1}+\sum_{j=0}^{p} \delta_{2} \Delta \operatorname{lnIR} t \\
& +\sum_{k=0}^{q} \delta_{3} \Delta \ln E X_{t-k}+\omega E C M_{t-1}+\varepsilon_{t} .
\end{aligned}
$$

\footnotetext{
${ }^{6}$ Or more simply, $D\left(\ln M C_{t}\right)=\beta_{1}+\beta_{I R} D\left(\ln I R_{t}\right)+\beta_{E X} D\left(\ln E X_{t}\right)+$
} $\beta_{\circ} U_{t-1}+\varepsilon_{t}$
In the above equation 3 , the coefficients with variables are called the short-run coefficients and the term $\left(\omega E C M_{t-1}\right)$ gives an idea about the speed of correction to long-run stability level which stay away the meaningless regression issue [38]. The presence of an adjustment parameter suggests the changes in explained variable $\left(\Delta \ln M C_{t}\right)$ which is a function of the disequilibrium levels in the cointegration relations plus the changes in other independent variables under consideration. This result shows the variations in explained variable from a short period of time to long-term equilibrium path [39]. It demonstrates the magnitude to which any variability in the preceding time is being adjusted in dependent variable. Its negative coefficient value confirms the convergence over the time. After estimating the ECM, we have employed the Variance Decomposition plus the Impulse Response Function to explore the dynamic feature of an error impulse for each included variable on its own upcoming dynamics plus in the forecast dynamics of the other determinants in the ECM analysis. The IRF is typically conducted after any vector model of the VECM which is employed to test out the impact of the coefficient over time, whereas; the variance decomposition determines the $\%$ age change of forecast error of variation that is explained by other variables within the short-run interactions.

The last step in this estimation procedure is to check for causality between aggregate market capitalization and its suggested determinants in the long-run. Causality is one of the important concepts used in time series econometrics, which is rather different to the daily usage concept; as it means more to the capability of one variable to envisage the second variable. In order to check out the pair wise causality between any two variables, Granger [40] presented a quite easy test, known as the Granger causality test. According to this test, a variable $Z_{t}$ is supposed to Granger cause $Y_{t}$ if the $Y_{t}$ can be foresees with immense precision by taking the past observations of the $\mathrm{Z}_{\mathrm{t}}$ variable rather than not using such precedence values, while keeping all the remaining terms as constant and vice versa. More to the point, this concept deals whether current and past values of $\mathrm{Y}_{\mathrm{t}}$ facilitate to forecast future values of $\mathrm{Z}_{\mathrm{t}}$. In a two variables case, say $Z_{t}$ and $Y_{t}$, the Granger causality can be written in a set of equations as follows:

$$
\begin{aligned}
& Z_{t}=\alpha_{1}+\beta_{i} Y_{t-i}+\gamma_{t} Z_{t-j}+\varepsilon_{1 t} \\
& Z_{t}=\alpha_{2}+\varphi_{i} Y_{t-i}+\omega_{t} Z_{t-j}+\varepsilon_{2 t} .
\end{aligned}
$$

The null hypothesis suggests that there is no casual relationship between any two variables in the whole system of the model which is tested against the alternative hypothesis, stating that there is a causal relationship found in the system.

\section{Results and Discussion}

The Johansen approach to cointegration can be applied to the dataset in finding the equilibrium relations between variables integrated of order one. If all variables are I (1) in nature, then the Johansen approach to cointegration is advisable due to its simple estimation practice. Therefore, we cannot use the Ordinary Least Squares (OLS) 
technique in the series if one of them is non-stationary due to the reason that these series will not act as constants anymore and some of them are time variant. The OLS technique will by mistake give high t-statistic values and significant outcomes, but in a real situation, it would not be the case.

\subsection{Statistical Analysis}

There are some opening steps which are needed to be carried out before going for a Johansen procedure to cointegration. Descriptive statistics provide summaries about the sample and about the observations that have been made. The summary of descriptive statistics of the whole data is reported in Table 1.

Table 1. Statistical Analysis Summary

\begin{tabular}{|l|c|c|c|}
\hline Statistic Name & $\operatorname{lnMC}$ & $\operatorname{lnIR}$ & $\operatorname{lnEX}$ \\
\hline Mean & 7.048053 & -2.195063 & 4.046945 \\
\hline Median & 7.432801 & -2.120264 & 4.092602 \\
\hline Maximum & 9.214738 & -1.609438 & 4.684443 \\
\hline Minimum & 3.884241 & -2.855970 & 3.183211 \\
\hline Standard Deviation (S.D) & 1.527565 & 0.335852 & 0.456562 \\
\hline Skewness & -0.307630 & -0.318871 & -0.379677 \\
\hline Kurtosis & 1.979560 & 2.389141 & 2.122603 \\
\hline Jarque-Bera (J-B) & 1.656483 & 0.909840 & 1.570851 \\
\hline Probability & 0.436917 & 0.634499 & 0.455926 \\
\hline Observations & 28 & 28 & 28 \\
\hline
\end{tabular}

Source: Output from EViews 9.

The above findings illustrate that the average of market capitalization is 7.05 with a S.D of 1.53 , the mean of interest rate is -2.20 with a S.D of 0.34 and the expected value of the exchange rate is 4.05 with a S.D of 0.46 . All variables of the model are negatively skewed. Besides, kurtosis statistic of the data showing that interest rate is leptokurtic and market capitalization is platykurtic. And finally, the J-B statistic shows that the residuals follow a normal distribution.

\subsection{Testing for Multicollinearity}

To test the presence of multicollinearity among regressors under consideration, a correlation test has been suggested in the econometric theory. The findings of the correlation test are given in Table 2. From the analysis of intercorrelations, we can conclude that our data has no issue of perfect multicollinearity as no one PCC between explanatory variables is more than 0.8 .

Table 2. Results of Intercorrelations

\begin{tabular}{|c|c|c|c|}
\hline Symbol & $\operatorname{lnMC}$ & $\operatorname{lnIR}$ & $\ln \mathrm{EX}$ \\
\hline $\operatorname{lnMC}$ & 1.000000 & -0.596031 & 0.704630 \\
\hline $\ln I R$ & -0.596031 & 1.000000 & -0.546236 \\
\hline $\ln \mathrm{EX}$ & 0.704630 & -0.546236 & 1.000000 \\
\hline
\end{tabular}

Source: Outcome from EViews 9

\subsection{Stationarity Test}

To estimate an equilibrium association between two series of data, the order of their integration is significant in deciding the appropriate procedure to cointegration. The ADF test results are given in Table 3.

The findings of the ADF test in Table 3 fail to reject the $\mathrm{H}_{0}$ hypothesis for all the series of data at the level. However, after first differencing the empirical outcomes indicate that $\operatorname{lnMC}_{\mathrm{t}}, \operatorname{lnIR}_{\mathrm{t}} \& \operatorname{lnEX_{\mathrm {t}}}$ are stationary at the $1 \%$ level of significance, showing that the entire series of data are integrated of order one. The below plot depicts the joint relationship of stationary and non-stationary series of dataset over the sample size, validating the above reported results of the ADF test.

Table 3. The ADF test Results

\begin{tabular}{|c|c|c|c|c|c|c|}
\hline \multicolumn{2}{|c|}{ Variables } & \multicolumn{2}{|c|}{ Intercept (C) } & \multicolumn{2}{|c|}{ Trend \& Intercept } & Conclusion \\
\hline & & $\beta$ & S. E & $\beta$ & S. E & \multirow{3}{*}{ I (1) } \\
\hline \multirow{2}{*}{$\mathrm{MC}_{\mathrm{t}}$} & Level & -0.046615 & 0.047950 & -0.058086 & 0.117716 & \\
\hline & Ist Difference & $-2.380358^{*}$ & 0.424643 & -2.434101 & 0.431710 & \\
\hline \multirow{2}{*}{$\mathrm{IR}_{\mathrm{t}}$} & Level & -0.090074 & 0.116984 & -2.543626 & 0.794654 & \multirow{2}{*}{ I (1) } \\
\hline & Ist Difference & $-0.925908 *$ & 0.198738 & -0.991831 & 0.208127 & \\
\hline \multirow{2}{*}{$\mathrm{EX}_{\mathrm{t}}$} & Level & -0.044645 & 0.028036 & -0.750808 & 0.306821 & \multirow{2}{*}{ I (1) } \\
\hline & Ist Difference & $-0.923726^{*}$ & 0.203776 & -0.981538 & 0.206895 & \\
\hline
\end{tabular}

Note: $(*)$ denotes stationary in each variable at the $5 \%$ level of significance. Source: Outcome from EViews 9.

(a) Trend with non-stationary series

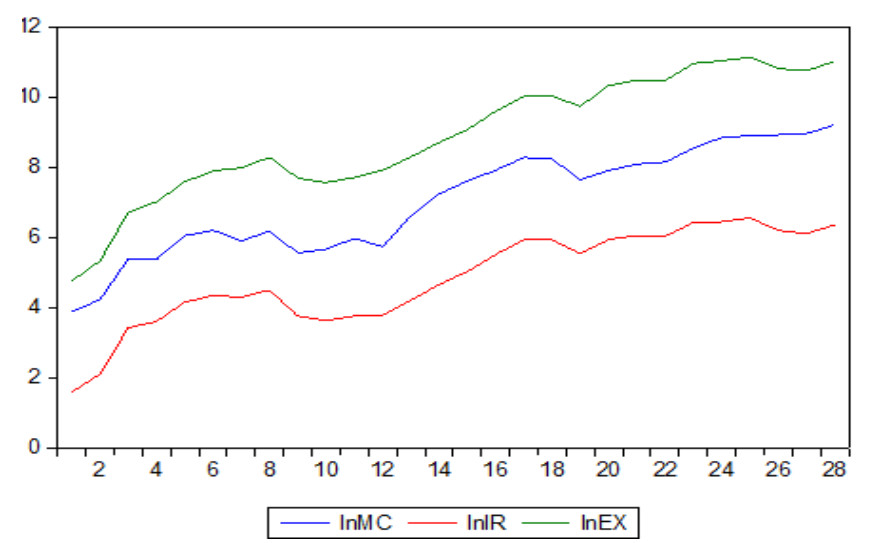

(b) Trend with stationary series

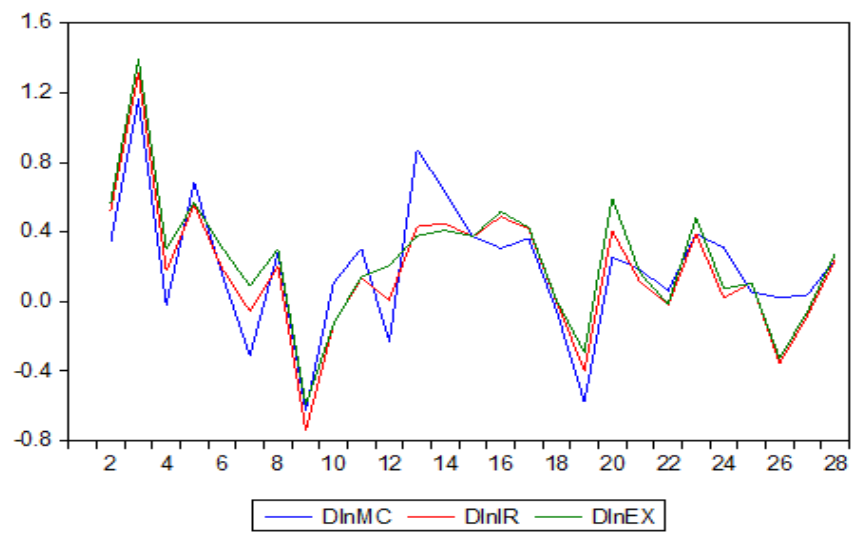

Figure 2. Trend with stationary and non -stationary series (1990-2017) (Source: Results extracted from the Eviews 9) 


\subsection{Ordinary Least Squares Regression Model}

All the log-transformed variables of the model have been chosen in developing the OLS regression model. The rationale of the OLS estimation at level is to discover the non-sense regression. If the empirical findings found spurious, then we are not in a position to further process the data for other time series analysis. In econometric theory, such results are known as meaningless regression results where $R^{2}$ becomes higher than the D-W statistic of the model and such results are undesirable for devising an effective economic policy in the economy. The OLS regression estimates show that $\mathrm{R}^{2}>\mathrm{D}-\mathrm{W}$ statistic which is the elementary criterion for having spurious regression. The OLS results of these statistics by estimating equation 1 are reported in Table 4.

Table 4. OLS Regression Results

\begin{tabular}{|l|c|c|c|c|}
\hline \multicolumn{5}{|c|}{$\begin{array}{c}\text { Explained Variable }=\operatorname{lnMC}_{\mathrm{t}} \\
\text { Method: OLS }\end{array}$} \\
\hline Variable & $\beta$ & S.E & t-statistic & p-value \\
\hline Intercept (C) & $-5.576657^{*}$ & 1.141187 & -4.886716 & 0.0000 \\
\hline InIR & -0.660504 & 0.443600 & -1.488965 & 0.1490 \\
\hline lnEX & $2.761308^{*}$ & 0.326316 & 8.462055 & 0.0000 \\
\hline $\mathrm{R}^{2}$ & 0.833151 & & 7.048053 \\
\hline Adj. $\mathrm{R}^{2}$ & 0.819803 & Mean dependent var & 1.527665 \\
\hline S.E. of regression & 0.648445 & S.D. dependent var & 2.072479 \\
\hline SSR & 10.51203 & $\begin{array}{l}\text { Akaike Information } \\
\text { Criterion (AIC) }\end{array}$ \\
\hline Log Likelihood & -26.01471 & \multicolumn{4}{l|}{ Schwarz Criterion (SC) } & 2.215215 \\
\hline F-statistic & 62.41805 & $\begin{array}{l}\text { Hannan-Quinn Criterion } \\
\text { (HQ) }\end{array}$ & 2.11615 \\
\hline Prob. (F-statistic) & 0.000000 & D-W statistic & 0.534789 \\
\hline Note: ${ }^{*}$ ) significance at the 1\% level \\
\hline
\end{tabular}

Source: Output from EViews 9.

Table 4 report findings from the OLS estimation of the relationship of aggregate market capitalization with interest rates and exchange rates. The F-statistic (62.49 with corresponding probability value 0 ) indicates that the overall regression model is statistically significant at the $1 \%$ level of significance and has a powerful explanatory power $\left(\mathrm{R}^{2}\right.$ is 0.83$)$. The coefficient of exchange rate is also statistically significant at the $1 \%$ level of significance as shown by the t-statistic (which is more than the EngleGranger critical value) or the probability value, but such result was not the case for interest rate variable. It is concluded that the relation of market capitalization to interest rate is negative and with the exchange rate is positive. The finding is showing that in Pakistan, a 1\% rise in exchange rate (depreciation of Pakistani rupee in terms of a dollar) contributes $2.76 \%$ rise in market capitalization and a $1 \%$ rise in interest rate contributes $0.66 \%$ fall in the amount of market capitalization, correspondingly. Simply, the estimated model of equation 1 can be written as under in equation 5 :

$$
\widehat{\ln M C}=-5.58-0.66 \ln I R+2.76 \ln E X .
$$

\subsection{Residual Analysis}

As presented in Table 4, findings reveal that $\mathrm{R}^{2}>\mathrm{D}-\mathrm{W}$ statistic, indicating a sign of spurious regression estimation which was first developed by Yule $[41]^{7}$. However, the remedial measure is that if the residual $\left(\varepsilon_{t}\right)$ of the model given in equation 1 is found stationary at level, then it would be recommended to choose the model for further time series analysis yet in a circumstance in which $\mathrm{R}^{2}$ statistic is greater than the $\mathrm{D}-\mathrm{W}$ statistic. It also means that the variables in the model given in equation 1 such as market capitalization, interest rate and exchange rate are co-integrated. In other words, the model in equation 1 is called the long-run model and the coefficients will be called as long-run coefficients. Table 5 reports the stationarity of error term $\left(\varepsilon_{t}\right)$ derived from the OLS estimation of equation 1 at level as revealed by the ADF test with $\mathrm{H}_{0}$ that the residual has a unit root.

Table 5. Residual unit root test

\begin{tabular}{|l|c|c|}
\hline Variable & Statistic & Probability Value \\
\hline Residual $(\varepsilon)$ & $-4.692135^{*}$ & $0.0011^{* *}$ \\
\hline $\begin{array}{l}\text { Test Critical Values: } \\
1 \%\end{array}$ & -3.737853 & \\
\hline $5 \%$ & -2.991878 & \\
\hline $10 \%$ & -2.635542 & \\
\hline $\begin{array}{l}\left(^{*}\right) \text { indicates significance at the 1\% level of significance } \\
(* *) \text { denotes MacKinnon (1996) one-sided p-values }\end{array}$ \\
\hline
\end{tabular}

Source: Outcome form EViews 9.

The graphical view of residual series as denoted by $U$ also confirms the stationary property as the residual curve has a mean-reverting behavior as the time passes. Besides, the Jarque-Bera statistic for checking normality yields that the residuals follow a normal distribution.

\subsection{Testing for Serial Correlation}

Serial correlation is commonly found in time series data and is regarded as the issue of time series data. The Breusch-Godfrey LM test is the widely recognized test for checking the occurrence of autocorrelation as alternative tests carry several issues. To avoid problems, Breusch and Godfrey [42] introduced an LM test which is used here for such purpose.

$H_{0}$ : Residuals are not serially correlated

$H_{0}$ : Residuals are serially correlated.

The LM test verdicts are reported in Table 6 which shows that there exist serial correlations, and hence we reject $H_{0}$ at the $5 \%$ level of significance.

Table 6. Results of the Breusch-Godfrey test

\begin{tabular}{|c|c|c|c|c|}
\hline \multicolumn{5}{|c|}{ Breusch-Godfrey Serial Correlation LM Test } \\
\hline \multicolumn{5}{|c|}{ Second-order S.C } \\
\hline F-statistic & 13.48505 & Prob. F (2, 23) & 0.0001 & Conclusion \\
\hline Obs* R & 15.11229 & Prob. Chi-Square (2) & 0.0005 & $\begin{array}{c}\text { Serial } \\
\text { Correlation }\end{array}$ \\
\hline
\end{tabular}

Source: Outcome from EViews 9.

\footnotetext{
${ }^{7}$ In the words of Granger and Newbold, "if value of an $\mathrm{R}^{2}$ is more than value of the D-W statistic, then it is agreeable rule of thumb to guess that the model in question is non-sense.
} 


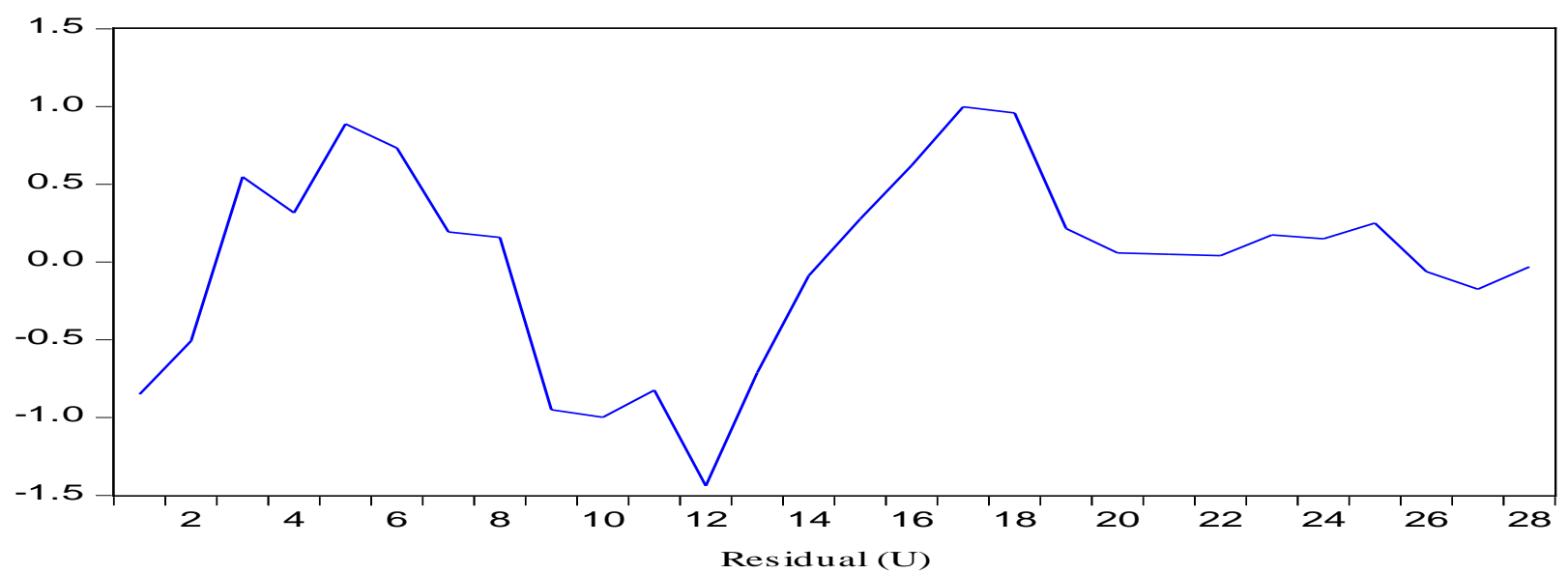

Figure 3. Plot of Stationary of residual at level (Source: Results extracted from the Eviews 9)

\subsection{Optimal Lags Selection:}

As results of the long-run relations among variables are highly responsive to lag length specified in the econometric models [43]. There are many criteria for choosing the order of optimum lag length, but the most important criterion among them are the AIC and SC. In this paper, the optimum lag is selected on the ground of minimum AIC value. According to the AIC criterion, one lag should be used before going for the long-run equilibrium relation. The same result has been confirmed from the other selection criteria.

\subsection{Testing for Cointegration}

The important stage in this analysis is to check for cointegration. Based on the information presented in Table 3, all the variables are found I (1), therefore suitable methodology is the Johansen approach to estimate the equilibrium association between the considered series. In order to discover the no of cointegrating equations in the whole setup, the Johansen cointegration test uses two major statistics such as maximum Eigen value as well as Trace statistic. The findings of both tests are reported in Table 8 and Table 9.

Table 7. Appropriate lag length selection

\begin{tabular}{|c|c|c|c|c|c|c|}
\hline \multicolumn{9}{|c|}{ VAR Lag Order Selection Criteria } \\
\hline Lag & LogL & LR & FPE & \multicolumn{2}{c|}{ AIC } & HC \\
\hline 0 & -37.40313 & ---107933 & 3.253098 & 3.149735 \\
\hline 1 & 56.04694 & $158.1463^{*}$ & 6.004491 & $-3.388226^{*}$ & $-2.807566^{*}$ & $-3.221017 *$ \\
\hline 2 & 60.76854 & 6.900808 & $9.81 \mathrm{e}-06$ & -3.059119 & -2.042964 & -2.766503 \\
\hline *indicates lag order selected by the criterion
\end{tabular}

Source: Outcome from EViews 9.

Table 8. Cointegration test results (Trace)

\begin{tabular}{|c|c|c|c|}
\hline \multicolumn{2}{|c|}{ Hypothesized } & \multirow{2}{*}{ Trace Statistic } & 5\% \\
\cline { 1 - 2 } No. of CE (s) & Eigen value & 33.43672 & 29.79707 \\
\hline None* & 0.437267 & 18.48801 & 15.49471 \\
\hline At Most 1* & 0.410651 & 4.740864 & 3.841466 \\
\hline At Most 2* & 0.166683 & 0.0182 \\
\hline $\begin{array}{l}* \\
* * \text { confirms rejection of the hypothesis at the 5\% level }\end{array}$ \\
\hline
\end{tabular}

Trace test shows 3 co-integrating vectors at the $5 \%$ level Source: Outcome from EViews 9.

Table 9. Cointegration test results (Maximum Eigen value)

\begin{tabular}{|c|c|c|c|c|}
\hline \multicolumn{2}{|c|}{ Hypothesized } & \multirow{2}{*}{ Maximum Eigen Statistic } & \multirow{2}{*}{$\begin{array}{c}5 \% \\
\text { Critical Value }\end{array}$} & \multirow{2}{*}{ P-values** } \\
\hline No. of CE (s) & Eigen value & & & \\
\hline None* & 0.437267 & 21.13162 & 14.94871 & 0.0325 \\
\hline At Most $1^{*}$ & 0.410651 & 14.26460 & 13.74715 & 0.0402 \\
\hline At Most $2 *$ & 0.166683 & 4.740864 & 3.841466 & 0.0294 \\
\hline
\end{tabular}

Max-Eigen value test shows 3 cointegrating vectors at the $5 \%$ level Source: Outcome from EViews 9. 
Both the Trace and maximum Eigen statistic recognized 3 cointegrating equations in the whole system as can be depicted that $\mathrm{H}_{0}$ of no cointegrating equation is straightforwardly declined at $95 \%$ level as the trace statistic value is more than the critical value at $5 \%$ significance level. Hence, we can conclude that all the three variables in the model are cointegrated with one another. Subsequent to normalizing the cointegrating vector on the stock market capitalization, the normalized co-integrating parameters were determined as given in Table 10.

Table 10. Normalized Cointegrating Coefficients

\begin{tabular}{|l|c|c|}
\hline $\ln \mathrm{MC}$ & $\operatorname{lnIR}$ & $\operatorname{lnEX}$ \\
\hline 1.000000 & 0.229758 & -3.165723 \\
\hline S.E & 0.72010 & 0.47538 \\
\hline t-statistic & -2.35132 & 3.74689 \\
\hline p-value & $0.06545^{*}$ & $0.01333^{* *}$ \\
\hline
\end{tabular}

Note: $(* *)$ and $(*)$ illustrate statistically significant at the $5 \%$ \& $10 \%$ level, correspondingly.

Source: Outcome from EViews 9.

The long-run model reported in Table 10 has a serious problem because the coefficient of interest rate is positive that is against the economic theory. Hence, the above coefficient signs are overturned due to the normalization procedure. So, the Johansen long-run cointegrating equation can be written in equation 6 as follows:

$$
\ln M C=-0.23 \ln I R+3.17 \ln E X .
$$

This long-run cointegrated equation now undoubtedly confirms that the bank rate has a negative plus the exchange rate has a positive effect on the equity market indicator in the long-term. The long-run linkage between market capitalizations as well as the rest explanatory variables has been established statistically significant. These findings imply that in Pakistan, a 1\% rise in interest rate and in exchange rate contributes $0.23 \%$ decrease and $3.17 \%$ increase in stock market performance in the long term, respectively. These results are in accordance with the findings of many empirical works that investigate the connection between equity market performance and interest rate/exchange rate, for example, Ahmad et al. [5], Mukit [4], Mbulawa [2], Mouna and Anis [44], etc.

\subsection{Error Correction Model Analysis}

The ECM proposed by Engle-Granger is a technique for analyzing the short-term behavior of variables in an econometric model. The fundamental prerequisites for application of the ECM are cointegration of variables and non-spurious regression. The findings of cointegration test (Table 8 and Table 9) present sufficient evidence on the long-term relations between the variables included in the model as there are three co-integrating equations in the system model. Alternatively, the verdict of the ADF test reports complete evidence of stationary of residual (Table 5) at level, and its graphical representation also confirms the same idea. Both these two prerequisites have confirmed that market capitalization, interest rate plus exchange rate are co-integrated plus non-spurious and provided a basis to analyze the ECM (equation 3). The empirics of the ECM are reported in Table 11 below.
Table 11. Results of the ECM analysis \& diagnostic tests

\begin{tabular}{|c|c|c|c|c|}
\hline \multicolumn{5}{|c|}{$\begin{array}{c}\text { Response }=\mathrm{D}\left(\operatorname{lnMC}_{\mathrm{t}}\right) \text { or } \Delta \ln M C_{t} \\
\text { Method: Least Squares (OLS) }\end{array}$} \\
\hline Variable & Coefficient & S.E & t-statistic & p-value \\
\hline Constant $\left(\delta_{1}\right)$ & 0.346636 & 0.097527 & 3.554241 & 0.0017 \\
\hline$\Delta \ln I_{\mathrm{t}}$ & $-0.257171^{* *}$ & 0.442601 & 2.581045 & 0.05669 \\
\hline$\Delta \ln E X_{t}$ & $2.584346 *$ & 1.230988 & -2.099408 & 0.0470 \\
\hline $\mathrm{ECM}_{\mathrm{t}-1}$ & $-0.220730^{* *}$ & 0.112305 & -1.964555 & 0.0615 \\
\hline R-squared & & & & 0.347665 \\
\hline Adj. R-squared & & & & 0.262578 \\
\hline D-W statistic & & & & 1.992664 \\
\hline
\end{tabular}

Source: Outcome from EViews 9.

From an estimate of the $\mathrm{R}^{2}$ statistic plus the $\mathrm{D}-\mathrm{W}$ statistic we can conclude that the ECM is no non-sense regression model. The coefficient of interest rate $\left(\delta_{2}\right)$ is negative signifying that there is negative relationship between $\Delta \ln M C_{t}$ and $\Delta \operatorname{lnIR}$. This short-run equilibrium coefficient is significant at the 10 percent level as pointed by the standard t-test or its corresponding p-value. It suggests that a $1 \%$ increase in interest rate will carry a decrease in market capitalization by about $0.25 \%$ in the short period. In contrast, the coefficient of exchange rate $\left(\delta_{3}\right)$ is positive telling that there is a direct connection between $\Delta \ln M C_{t}$ and $\Delta \operatorname{lnEX}$. This short-run equilibrium coefficient is significant at the $5 \%$ level as shown by the standard t-test. The estimated value of $\delta_{3}$ is 2.584346 which means that a $1 \%$ increase in exchange rate will raise market capitalization by about $2.58 \%$ in the short-run. The last term of the table $\left(\mathrm{ECM}_{\mathrm{t}-1}\right)$ is the one period lag error of the ECM which actually corrects the disequilibrium of the system. The long-run coefficient $(\omega)$ of the lagged ECM is negative and statistically significant as desired at the $10 \%$ significance level, which provide validity to the situation of long-term linkage among the series. It concludes that the speed of adjustment from prior year's disequilibrium in a stock market of Pakistan is about $22.07 \%$ per annum. These empirical findings are in line with various studies on the same concern, such as Ahmad et al. [5], Mukit [4], Mbulawa [2], etc.

\subsection{Variance Decompositions}

To investigate the short-term dynamic aspects of market capitalization, we employ the variance decomposition which is commonly known as the forecast error variance decomposition (FEVD). It designates the amount of information each variable contributes to the other variables in the VAR (Vector Autoregression) models. It establishes how much of the forecast error variance of each of the variables can be explained by exogenous shocks to the other variables. The findings of the variance decomposition are mentioned in Table 12.

The findings of Table 12 indicate that dynamic behavior in aggregate market capitalization narrates 100\% variation of the fluctuation in the first year when the innovation by a S.D of 0.35 in the variable itself. In the short-run, that is period 3 , shock to market capitalization account for $97.39 \%$ variation of the fluctuation in market capitalization (own shock), whereas; impulse to interest rate plus exchange rate can cause $1.28 \%$ and $1.33 \%$ 
fluctuation in market capitalization, respectively but as a whole total fluctuation become 100 percent. While in the long-run, that is period 10, the shock to market capitalization can contribute $76.66 \%$ of market capitalization (own innovation), however; shock to interest rate and exchange rate can cause $6.17 \%$ and $17.17 \%$ of the variance of market capitalization, respectively. From the analysis, we can conclude that in the short run, the market capitalization can contribute more, but in the long-run, such contribution to market capitalization has gone down. But in case of both interest rate and exchange rate, such analysis becomes reversed and hence the story remained changed.

\subsection{Impulse Response Function (IRF)}

Generally the IRF is employed after the VAR specification. An IRF usually traces the upshot of a one positive S.D impulse or innovation to one variable and we see the effect of this shock on other variables or on the same variable. It means that it is just as forecasting about the response of economic variables in future times. Specifically, it designates the influence of a one S.D impulse in the interest rate plus exchange rate on the aggregate market capitalization of Pakistan. The result of impulse responses is shown in Figure 4.
From the graphs of the impulse responses, one can clearly see that the findings are in line with the findings of the variance decomposition. The plots conclude that bank rate has a converse impulse whereas, the exchange rate has a positive innovation on the market capitalization. Such findings seem in line with studies conducted by Mukit $[4,16]$.

Table 12. Results of the VAR Variance Decompositions

\begin{tabular}{|c|c|c|c|c|}
\hline \multicolumn{5}{|c|}{ Variance Decomposition of lnMC } \\
\hline Period & Standard Error & $\operatorname{lnMC}$ & $\operatorname{lnIR}$ & $\operatorname{lnEX}$ \\
\hline 1 & 0.354435 & 100.0000 & 0.000000 & 0.000000 \\
\hline 2 & 0.441451 & 99.02271 & 0.669269 & 0.308021 \\
\hline 3 & 0.477630 & 97.39408 & 1.275982 & 1.329941 \\
\hline 4 & 0.493502 & 95.30923 & 1.447560 & 3.243211 \\
\hline 5 & 0.502998 & 92.71948 & 1.393777 & 5.886743 \\
\hline 6 & 0.512064 & 89.61612 & 1.558603 & 8.825279 \\
\hline 7 & 0.522238 & 86.17402 & 2.220873 & 11.60510 \\
\hline 8 & 0.533144 & 82.69249 & 3.355778 & 13.95173 \\
\hline 9 & 0.543991 & 79.45970 & 4.749874 & 15.79043 \\
\hline 10 & 0.554190 & 76.66414 & 6.165922 & 17.16993 \\
\hline
\end{tabular}

Source: Outcome from EViews 9.

Response to Cholesky One S.D. Innovations

Response of LNMC to LNMC

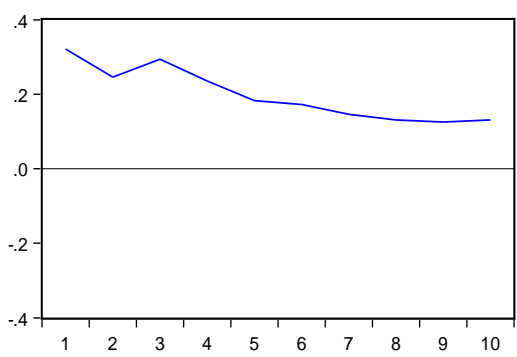

Response of LNIR to LNMC

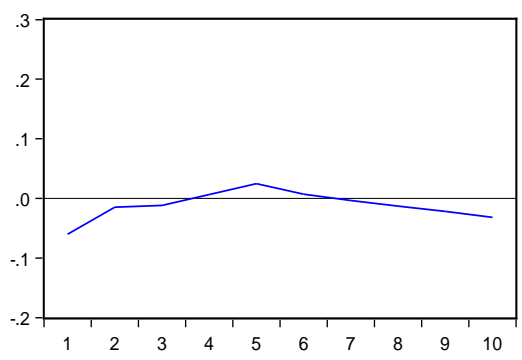

Response of LNEX to LNMC

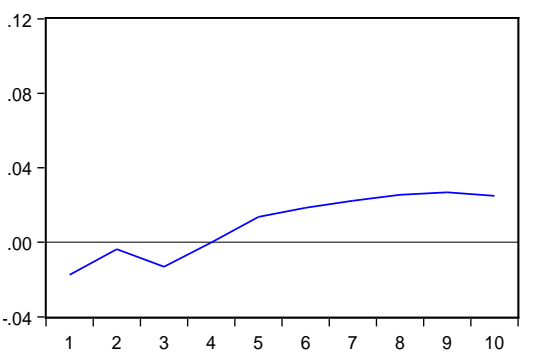

Response of LNMC to LNIR

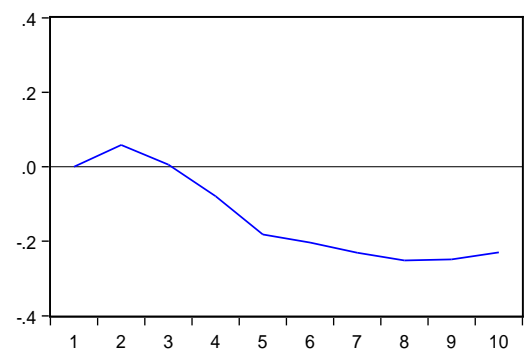

Response of LNIR to LNIR

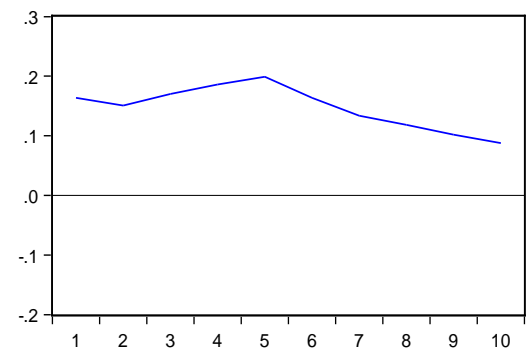

Response of LNEX to LNIR

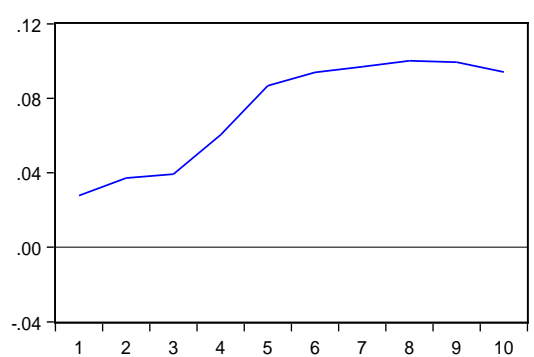

Response of LNMC to LNEX

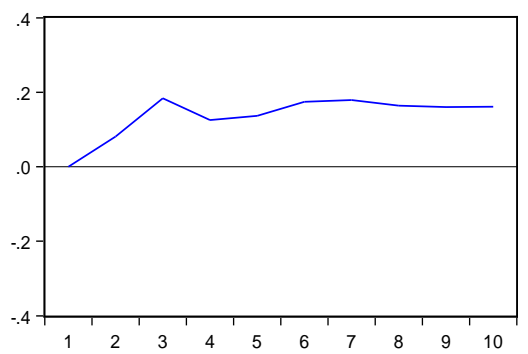

Response of LNIR to LNEX

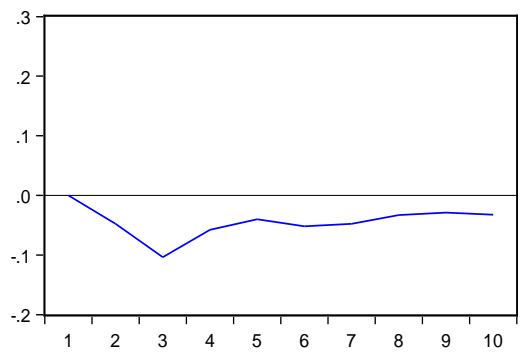

Response of LNEX to LNEX

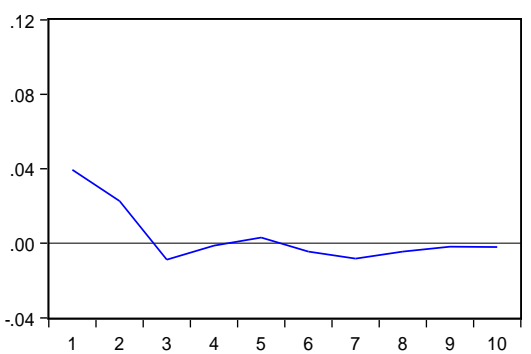

Figure 4. Plot of Impulse Response Function (IRF) (Source: Results extracted from the Eviews 9) 
Table 13. Results of Pairwise Granger Causality Tests

\begin{tabular}{|c|c|c|c|c|}
\hline \multicolumn{5}{|c|}{ Lags $=01$} \\
\hline Null Hypothesis ${ }^{\#}$ & Observations & F-statistic & P-value $^{@}$ & Granger Causality $^{\text {No }}$ \\
\hline$\Delta \ln I R \neq>\Delta \ln M C$ & 26 & 0.99254 & 0.3295 & No \\
\hline$\Delta \ln M C \neq>\Delta \ln I R$ & 26 & 2.14418 & 0.1566 & No \\
\hline$\Delta \ln E X \neq>\Delta \ln M C$ & 26 & 0.14469 & 0.7071 & No \\
\hline$\Delta \ln M C \neq>\Delta \ln E X$ & 26 & 0.01017 & 0.9205 & Yes \\
\hline$\Delta \ln E X \neq>\Delta \ln I R$ & 26 & 3.59040 & $0.0708^{*}$ & No \\
\hline$\Delta \ln I R \neq>\Delta \ln E X$ & 26 & 1.05875 & 0.3142 & \\
\hline
\end{tabular}

Note: (\#) The symbol $\neq>$ implies “does not Granger-cause”. Accordingly $\Delta \ln I R \neq>\Delta \ln M C$ means interest rate doesn’t Granger-cause market capitalization.

(@) F-statistic values are derived using lag 1 in related regression equations

$\left({ }^{*}\right)$ indicate statistically significant at the $10 \%$ significance level

Source: Outcome from EViews 9.

\subsection{Granger-Causality Test}

The last step of empirical investigation is to check for a causal relationship between aggregate market capitalization and its major determinants in the long-term. For such intention, we apply a well-known Granger-causality test to investigate whether projected variables in the proposed model are causally related at least in one direction with one lag length. Table 13 presents values of the F-statistics \& p-values created under the $\mathrm{H}_{0}$ of non-causality between variables in the whole setup.

The findings of the Granger causality test indicate that merely a causal relationship has been found between the pair of exchange rate-interest rate in the long-run, meaning that there is a unidirectional causality from an exchange rate to interest rate. And such output is statistically significant at the $10 \%$ level. However, no such results have been found in the rest of pairs in the whole system and therefore, we accept the null hypotheses that these variables have no causality in the long-term. The evidence is reliable with the result of Mbulawa [2].

\section{Conclusion and Policy Implications}

This paper attempts to investigate the short-term as well as the long-term linkage between aggregate market capitalization and interest rates plus exchange rates taking the Pakistan annual data for the period of 1990 to 2017 by employing a set of econometric techniques. The proposed regression model seems not spurious as checked. The result of the ADF test illustrates that the entire variables under concern are not stationary at level, but stationary at their first difference. The Johansen Jeselius approach to cointegration recommends that all three series of data are co-integrated among themselves having the strong longrun relationship. The findings of the Johansen test show that in the long-period the interest rate has an inverse and the exchange rate has a positive impact on the stock market volatility of Pakistan where the parameter estimates of all the regressors are found statistically significant. The estimates of the ECM analysis imply that in a short-run a $1 \%$ increase in interest rate and exchange rate will bring about $0.25 \%$ and $2.58 \%$ decrease and increase in market capitalization of the PSX, respectively. The estimated coefficient of the ECM model suggests that about $22.07 \%$ divergence of the stock market capitalization from its long-term stability level is adjusted each year in the short time. The variance decomposition analysis depicts that in the short-run the market capitalization can contribute more when compared with the long-run. Such findings are clearly confirmed by analysis of the impulse response function. The finding of the Granger causality analysis indicates that there exists a unidirectional causality from the exchange rate to the interest rate, though; no such causal relationship has been found in the rest of the variables in the whole system.

In this background, this research study has some policy suggestions so as to further boost the financial sector of Pakistan. The vibrant stock market can be highly encouraged by further reducing the interest rate by the regulatory authority of the monetary policy under the State Bank of Pakistan. High bank rates were helpful in discouraging the higher economic growths, wherein, the low bank rate would encourage stock market financial activity. This policy will also control the high rates of inflationary trends in the economy. In addition, the regulatory authorities of the central bank are hereby advised to prepare such an expansionary monetary policy which brings new investors into the stock market of Pakistan for business and will have accordingly favorable effect on the same market. If the stock market becomes well-developed, the depreciation of the exchange rate will be automatically stable. The results of this work also help overseas investors to consider the explosive nature of the PSX market into concern while making the decision to invest here since the stock market volatility brings change in exchange rates so foreign investors can also foresee their exchange risk on account of instability of stock returns.

\section{References}

[1] Tripathi, V., Seth, R. (2014), "Stock Market Performance and Macroeconomic Factors: The Study of Indian Equity Market", Global Business Review, Vol. 15, Issue 2, pp. 291-316.

[2] Mbulawa, S. (2015), "Effect of Macroeconomic Variables on Economic Growth in Botswana", Journal of Economics and Sustainable Development, Vol. 6, Issue 4, pp. 68-78.

[3] Akhtar, D. S. (2006), "Pakistan’s Financial Services Sector - A Future Prospective”, Statistics Department, State Bank of Pakistan, pp. 1-9.

[4] Muktadir-al-Mukit, D. (2012), "Effects of Interest Rate and Exchange Rate on Volatility of Market Index at Dhaka Stock Exchange”, Journal of Business and Technology (Dhaka), Vol. 7, Issue 2, pp. 1-18. 
[5] Ahmad, M. I., Rehman, R., Raoof, A. (2010), "Do Interest Rate, Exchange Rate effect Stock Returns? A Pakistani Perspective”, International Research Journal of Finance and Economics, Issue 50, pp. 146-150.

[6] Kutty, G. (2010), “The Relationship between Exchange Rates and Stock Prices: The Case of Mexico”, North Americal Journal of Finance and Banking Research, Vol. 4, Issue 4, pp. 1-12.

[7] Abraham, T. W. (2011), "Stock Market Reaction to Selected Macroeconomic Variables in the Nigerian Economy", CBN Journal of Applied Statistics, Vol. 2, Issue 1, pp. 61-70.

[8] Aslam, W. (2014), "Relationship between Stock Market Volatility and Exchange Rate: A Study of KSE”, Journal of Public Administration, Finance and Law, Issue 5, pp. 62-72.

[9] Ihsan, A., Baloch, Q. B., Kakakhel, S. J. (2015), "Relationship between Exchange Rates and Stock Market Index: Evidence from the Pakistani Stock Market”, Abasyn Journal of Social Sciences, Vol. 8, Issue 1, pp. 17-36.

[10] Kanasro, H. A., Jalbani, A. A., Junejo, M. A. (2009), "Stock Market Liquidity: A Case Study of Karachi Stock Exchange”, Pakistan Journal of Commerce and Social Sciences, Vol. 3, pp. 25-34.

[11] Sichoongwe, K. (2016), "Effects of Exchange Rate Volatility on the Stock Market: The Zambian Experience”, Journal of Economics and Sustainable Development, Vol. 7, Issue 4, pp. 114-119.

[12] Joseph, N. L., Vezos, P. (2006), "The Sensitivity of US Bank's Stock Returns to Interest Rate and Exchange Rate Changes”, Managerial Finance, Vol. 32, Issue 2, pp. 182-199.

[13] Modigliani, F. (1971), "Monetary Policy and Consumption: Linkages via Interest Rate and Wealth Effects in the FMP Model, Consumer Spending and Monetary Policy: The Linkages”, Federal Reserve Bank of Boston Conference Series, Conference Series No. 5, June 1971.

[14] Mishkin, F. (1977), "What Depressed the Consumer? The Household Balance Sheet and the 1973-1975 Recession”, Brookings Papers on Economic Activity, Vol. 1, pp. 123-164.

[15] Fama, E. F., Schwert, G. W. (1977), “Asset Returns and Inflation”, Journal of Financial Economics, Vol. 5, pp. 115-146.

[16] Muktadir-al-Mukit, D. (2013), "The Effects of Interest Rates Volatility on Stock Returns: Evidence from Bangladesh”, International Journal of Management and Business Research, Vol. 3, Issue 3, pp. 269-279.

[17] Kasman, S. (2003), “The Relationship Between Exchange Rates and Stock Prices: A Causality Analysis”, DokuzEylul Institute for Social Sciences, Vol. 5, Issue 2, pp. 70-79.

[18] Nath, G. C., Samanta, G. P. (2003), "Relationship Between Exchange Rate and Stock Prices in India - A Empirical Analysis”, pp. 1-11.

[19] Mlambo, C., Marezda, A., Sibanda, K. (2013), "Effects of Exchange Rate Volatility on the Stock Market: A Case Study of South Africa”, Mediterranean Journal of Social Sciences, Vol. 4, Issue 14, pp. 561-570.

[20] Bhat, K. U., Shah, S. Z. A. (2015), "Empirical Investigation of the Relationship between Exchange Rate Movements and Stock Market Volatility in the Context of Pakistan”, Pakistan Business Review, pp. 744-758.

[21] Solnik, B. (1987), "Using Financial Prices to Test Exchange Rate Models: A Note”, The Journal of Finance, Vol. 42, Issue 1, pp. 141-149.

[22] Hasan, A., Javed, M. T. (2009), "Macroeconomic Influences and Equity Market Returns: A Study of an Emerging Equity Market”, Journal of Economics and Economic Education Research, Vol. 10, Issue 2, pp. 47-68.

[23] Geetha, C., Mohidin, R., Chandran, V. V., Chong, V. (2011), “The Relationship between Inflation and Stock Market: Evidence from Malaysia, United States and China”, International Journal of Economics and Management Sciences, Vol. 1, Issue 2, pp. 1-16.

[24] Rabia, N., Khakan, N. (2015), "Impact of Macro Variables on Karachi Stock Exchange”, Journal of Tourism and Hospitality, Vol. 4, Issue 4, pp. 1-5.

[25] Kennedy, K., Nourizad, F. (2016), "Exchange rate volatility and its effect on stock market volatility”, International Journal of
Human Capital in Urban Management (IJHCUM), Vol. 1, Issue 1, pp. 37-46.

[26] Cameron, S. (1994), "A review of the econometric evidence on the effects of capital punishment”, Journal of Socio-Economics, Vol. 23, Issue 1-2, pp. 197-214.

[27] Ehrlish, I (1975), “The deterrent effect of capital punishment - A question of life and death”, American Economic Review, Vol. 65, Issue 3, pp. 397-417.

[28] Ehrlish, I (1996), "Crime, Punishment and the Market for Offences”, Journal of Economic Perspectives, Vol. 10, Issue 1, pp. 43-67.

[29] Aggarwal, R. (1981), "Exchange Rates and Stock Prices: A Study of the U.S. Capital Markets under Floating Exchange Rates”, Akron Business and Economic Review, Vol. 12, pp. 7-12.

[30] Smith, C. (1992), "Stock Market and Exchange Rate: A Multicountry Approach”, Journal of Macroeconomics, Vol. 14, Issue 4, pp. 607-629.

[31] Sabri, N. R. (2004), "Stock Return Volatility and Market Crisis in Emerging Economics”, Review of Accounting and Finance, Vol. 3 Issue 3, pp. 59-83.

[32] Soenen, L. A., Hennigar, E. S. (1988), “An Analysis of Exchange Rates and Stock Prices: the U.S. Experience between 1980 and 1986”, Akron Business and Economic Review, Vol. 19, pp. 7-16.

[33] Granger, C. W. J., Huang, B., Yang, C. W. (1998), “A Bivariate Causality between Stock Prices and Exchange Rates: Evidence from the Recent Asia Flu”, Unpublished Work, Department of Economics, University of California, San Diego.

[34] Yusuf, M. M., Rahman, H. A. (2012), "Causality Effect between Equity Market and Exchange Rate Volatility in Malaysia”, International Proceedings of Economics Development and Research (IPEDR), Vol. 55, Issue 22, pp. 109-114.

[35] Gujarati, D. N. (2004), "Basic Econometrics”, 4th Edition, The McGraw-Hill Companies.

[36] Nkoro, E., Uko, A. K. (2016), "Exchange Rate and Inflation Volatility and Stock Prices Volatility: Evidence from Nigeria, 1986-2012”, Journal of Applied Finance and Banking, Vol. 6, Issue 6, pages 4.

[37] Johansen, S., Jeselius, K. (1990), “The Maximum Likelihood Estimation and Inference on Cointegration-with Application to Demand for Money”, Oxford Bulletin of Economics and Statistics, Vol. 52, pp. 169-210.

[38] Engle, R. F., Granger, C. W. J. (1987), “Co-integration and Error Correction Representation, Estimation and Testing”, Econometrica, Vol. 55, pp. 251-276.

[39] Masih, A., Masih, R. (1997), “On the temporal causal relationship between energy consumption, real income, and prices: Some new evidence from Asian-energy dependent NICs Based on a multivariate cointegration/vector error correction approach”, Journal of Policy Modelling, Vol. 19, Issue 4, pp. 417-440.

[40] Granger, C. W. J. (1969), "Investigating Causal Relations by Econometric Models and Cross Spectral Methods”, Econometrics, Vol. 35, pp. 224-238.

[41] Yule, G. U. (1926), "Why Do We Sometimes Get Nonsense Correlations Between Time Series? A Study in Sampling and the Nature of Time Series”, Journal of the Royal Statistical Social Sciences, Vol. 89, pp. 1-64.

[42] Breusch, T. (1978), "Testing for Autocorrelation in Dynamic Linear Models”, Australian Economic Papers, Vol. 17, pp. 334-355.

[43] Bahmani-Oskooee, M., Bohl, M. T. (2000), "German monetary unification and the stability of the German M3 money demand function”, Economics Letters, Vol. 66, Issue 2, pp. 203-208.

[44] Mouna, A., Anis, J. (2017), "Financial Literacy in Tunisia: Its determinants and its implications on investment behaviour", Research in International Business and Finance, Vol. 39 (Part A), pp. 568-577.

[45] Pakistan, Government of (various issues) Pakistan Economic Survey, Ministry of Finance, Government of Pakistan, Islamabad.

[46] Pakistan, Statistics and DWH Department \& Domestic Markets and Monetary Management Department \& External Relations Department \& Monetary Policy Statement, State Bank of Pakistan (2016, 2017), Islamabad. 